This document is a manuscript version of the following article:

Title: Collective Public-Transport Tickets and Anticipated

Majority Choice: A Model of Student Tickets

By: Voß, Achim

Published in: Transportation Research Part A: Policy and Practice -

Volume 80, October 2015, Pages 263-276

Publisher: Elsevier | Year: 2015

DOI: 10.1016/j.tra.2015.08.005

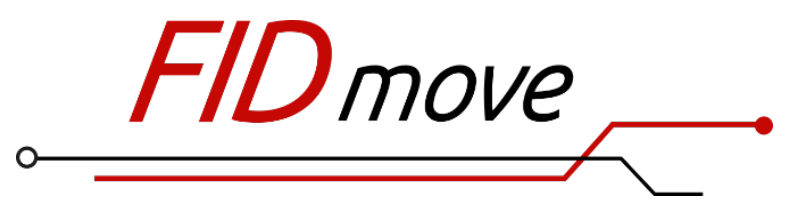

Brought to you by the Scientific Information Service for Mobility and Transport Research

Fachinformationsdienst Mobilitäts- und Verkehrsforschung

Website: www.fid-move.de

Repository: publish.fid-move.de

Contact: publish@fid-move.de

(C) 2015. This manuscript version is made available under the CC-BYNC-ND 4.0 license.

http://creativecommons.org/licenses/by-nc-nd/4.0/ 


\title{
Collective Public-Transport Tickets and Anticipated Majority Choice: A Model of Student Tickets*
}

\author{
Achim Voss ${ }^{\dagger}$ \\ Transportation Research Part A: Policy and Practice \\ Version accepted on 10 August 2015
}

\begin{abstract}
In Germany, many universities have student tickets that are bargained for between student representatives and public transport companies, approved by referendum, and mandatory for all students. They allow the use of public transport at no additional cost. I analyze such a scenario in a theoretical model as an example of a flat-rate ticket for public transport which is implemented by majority decision. The mandatory character of the ticket reduces transaction costs like marketing and ticket inspection, reducing the ticket price and thus the students' commuting expenses. However, there is a countervailing effect. Students face and rationally expect zero marginal monetary commuting costs, so that new students choose a place of residence which is relatively far from the university. This in turn raises the equilibrium ticket price. It may even be the case that students would be better off if such a ticket had never existed. Nonetheless, they always vote for it in referenda, because accepting the high price is optimal given their place of residence. After laying out the model, I analyze an optimal policy, which consists, for example, of subsidizing student dorms at an efficient distance to the city center.
\end{abstract}

Keywords: Public Transport; Collective Price Bargaining; Location Choice; Transaction Costs; Universities; Fare-Free Public Transport

JEL Codes: R41; D71

\section{Introduction}

In many parts of Germany, a "Semesterticket" is one of the advantages of being a student. For this kind of transit pass, all students pay at the beginning of the semester and may then use public transport free of additional cost. This includes bus usage in the university city, but at many universities, it covers much more, including trains in the region, or even the complete public transport network in the State (e.g. North Rhine-Westphalia). The Semesterticket - which

\footnotetext{
*Thanks to Manuel Förster, Anke Gerber, Corina Haita-Falah, Gernot Sieg, Mark Schopf, Colin Vance, and two anonymous reviewers for helpful comments and suggestions, and to Brian Bloch for editing and proofreading the manuscript. I owe special thanks to the student committees, student service organizations, university administrations and publictransport companies that provided me with data on the student-ticket price development.

†University of Hamburg, Department of Economics, University of Hamburg, Von-Melle-Park 5, 20146 Hamburg, Germany. Tel.: +4940 42838 4529. E-mail: achim.voss@wiso.uni-hamburg.de.

thttp://dx.doi.org/10.1016/j.tra.2015.08.005 - (c) 2015. This manuscript version is made available under the CC-BY-NC-ND 4.0 license http://creativecommons.org/licenses/by-nc-nd/4.0/
} 
I refer to simply as "student ticket" in the following analysis - has developed in the German tradition of student self-administration; It was originally proposed by student councils, it is bargained between them and the bus and train companies, and regularly has to be approved by a referendum 1

Originally, these tickets were controversial, because once introduced, they are mandatory for all students at the respective university. Nonetheless, a large majority of students usually favors the ticket in referenda. Moreover, courts have backed their legitimacy. In 2000, the German Federal High Court rejected a constitutional complaint against the student ticket (BVerfG, 2000). According to the court, the aim of reducing students' living expenses is a cogent justification for making the ticket mandatory. In particular, the court accepted the intuitively appealing idea that bargaining for a large number of tickets enables the student representatives to obtain a high discount. The large, guaranteed demand in turn depends on the mandatory character.

This justification, however, is worthy of a closer analysis. For the students to have bargaining power, there must be something for the transport companies to gain through such an agreement. A simple threat not to buy any tickets would hardly be credible. After all, public transport is essential for most students, so that without a student ticket, they will have to buy ordinary tickets individually.

So what can the public-transport companies gain from an obligatory ticket? One important aspect is clearly that of redistribution. The student ticket implies that students who own and use a car are forced to pay for buses and trains. Part of these non-user payments are additional revenues for the transport companies, and the remainder reduces costs for the other students. Courts and student committees justify every student having to pay without directly benefiting from the ticket by referring to the principle of solidarity inherent to the student community ${ }^{2}$

However, outright redistribution is never referred to as a justification for the ticket, but merely as a disadvantage that has to be accepted to make the student ticket possible. In this paper, I therefore focus on a different point. If all students have to pay for the ticket without explicitly purchasing it, some forms of transaction cost can be eliminated. For instance, specific marketing is no longer necessary, and ticket-control costs and fare evasion can be reduced. Such transactioncost savings can be achieved if the students and the transport companies agree on a student-ticket contract. The student benefit from the ticket agreement is that some of the transaction-cost savings are passed on to them, potentially reducing the commuting costs of all students.

A student-ticket deal would thus be beneficial for both sides, although this does not seem to be the end of the story. After the student ticket has been introduced, a usual pattern is that student usage of public transport grows strongly, accompanied by marked price increases (see Section 2 and Weichbrodt, 2001, pp. 8-10). It is easy to find a reason for this. A flat-rate ticket implies that students do not take marginal transportation costs into account. This can be expected to increase their public-transport usage, which in turn raises costs. Thus, the ticket price will have to include this cost increase, which in turn raises some questions. Under which circumstances are collective flat-rate tickets still beneficial for students? Is it possible that students still support them if they are in some sense not really beneficial to them? And would a political intervention definitely increase efficiency?

In this paper, I use a simple model to consider these questions. I argue that it is natural that students benefit in the time immediately after the student ticket is introduced, due to the transaction-cost savings. Later cohorts of students, however, benefit less and may even be worse off, compared to a situation without a student ticket. The reason for this is that expectations of the flat-rate ticket's existence alter new students' choice of their place of residence, which increases the commuting distance, and thus, the equilibrium student-ticket price.

\footnotetext{
${ }^{1}$ At least, this summarizes the typical case. Details may vary; see Section 2

${ }^{2}$ For details concerning this term, see Section 2
} 
The introduction of a mandatory ticket enforces a uniform price by majority decision, so that the framework is that of a political-economy model of location and commuting choices. The student ticket has the direct beneficial effect of reducing costs. At the same time, it creates an externality; commuting costs become exogenous to the individual. When choosing a place of residence, new students anticipate the existence of a student ticket and thus live relatively far from the university to save rent. Afterwards, when voting on the ticket, they support it at the high costs that their commuting distance creates, because their place of residence would induce high transport costs anyway.

If the externality effect is stronger than the transaction-cost savings effect, the result may be a situation in which all students would prefer the collective ticket not to exist if they were asked before choosing their apartment. However, if those students who have already chosen their place of residence would announce their intention to vote against it in the future, so as to influence the location decision of new students, this announcement would be time-inconsistent. Under these circumstances, a rule by the local government forbidding the ticket in the first place would make students better off than the discretion to decide on the ticket by majority decision. This, however, would not be first-best optimal, as it would prevent the transaction-cost savings from being realized. Instead, an optimal policy implies exerting an influence on the students' choice of abode.

To the best of my knowledge, this dynamic problem has not been formally analyzed in the literature on decisions relating to collective tickets, public transport or location choice in general. More generally, the student ticket is an interesting example of a collective decision that has common gains, but comes with adverse side-effects. It increases economic efficiency by implementing a collective, obligatory purchase and thus doing away with costs that would otherwise be necessary to bring about individual demand. This decision, however, suppresses the incentive to take the costs of individual behavior into account, so that an externality is created as a side-effect. Individuals adjust to the expectation of zero marginal cost, and the net gain may be positive or negative, depending on the magnitude of avoidable costs.

In this context, the location of an apartment has two important characteristics. Firstly, location is a state variable that is costly to change. Secondly, the location of an individual determines her demand for transportation, so that her optimal location changes with her expected marginal transportation costs. Together, these characteristics imply that individuals may support the collective ticket in a referendum even if the adverse side-effect creates high costs. During the referendum, everybody has already chosen her apartment location and thus determined how much she will commute; thus, marginal-cost pricing would prevent transaction-cost savings, but bring no benefits.

The main contribution of this article is to formally analyze this dynamic problem, and the interaction between transaction-cost savings and incentives. To focus on these aspects, I do not consider other aspects of the collective ticket. In particular, I ignore the students' modal choice, assume that trips are for commuting to the university only, and I assume a population of identical students. The only source of heterogeneity in my model is that students who enroll at the university after the ticket introduction choose to live at a distance to the university that is different from the location choice before the student ticket existed. This is in contrast to Stähler (2000), who provides the only other formal analysis of the student ticket $]^{3}$ In his model, students exogenously differ in their willingness to pay. By making the purchase mandatory, the transport company receives additional revenues; it is willing to reduce the price in return so that the median student agrees. This may be considered a formalization of the idea to which the German Federal High Court also subscribes, as mentioned above. Due to the focus on heterogeneity, Stähler's argument is complementary to mine.

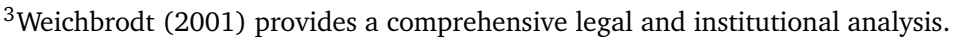


A second contribution of this article is to describe the institutional background and historical development of the student ticket in Germany, which I do in Section 2, along with brief case studies of the price development in eight university cities. This is not meant as a test of the theoretical model (for which additional aspects would have to be incorporated into the model), but to provide the empirical context for it. Nonetheless, I discuss the relation between the data and the model in the conclusions in Section 4. Due to the description of the student ticket in Germany, a second set of articles that is complementary to mine are the descriptions and empirical analyses of equivalent tickets in the US, the Unlimited Access programs, by Brown et al. (2001, 2003).

In my model, the fact that the student ticket applies to a small part of the population allows to assume, for example, apartment rents as exogenous. The insights derived from the model, however, may also be applicable to more general settings. For example, there are cities in which public transport is fully paid by taxes and usable at no additional charge, and there are proposals for such policies in other cities. Hasselt (Belgium) and Templin (Germany) are commonly cited examples. In both cities, fare-free public transport was introduced in 1997, but subsequently canceled due to increasing costs; for an assessment see Storchmann (2003) and Fearnley (2013). Fearnley also discusses the introduction of a fare-free system in the Estonian capital of Tallinn in 2013. The optimal policy that should accompany such a general flat-rate ticket may be similar to the optimal policy in the present paper.

There is further literature on city-wide season passes and similar voluntary flat-rate tickets (see, for example, Pucher and Clorer, 1992 and FitzRoy and Smith, 1998, 1999). A commonality of the student ticket with such voluntary flat-rate tickets exists, because in general discussions, the additional convenience of flat-rate tickets is often emphasized; for this, also see Levinson and Odlyzko (2008) and the survey in Schmale et al. (2013) and their empirical investigation of a flat-rate bias. This additional convenience is closely related to the argument of transactioncost reductions in my model. In general, however, such tickets are not directly comparable to mandatory tickets. For instance, voluntary demand by heterogeneous consumers may lead to price discrimination (as analyzed in the context of travel passes by Carbajo, 1988; for an empirical analysis of the determinants of demand for flat-rate tickets, see Vance and Peistrup, 2012). This is in contrast to the uniform price associated with a mandatory ticket.

This paper proceeds as follows. In the next section, I present a brief overview of the institutional background of the student ticket, accompanied by a few short case studies to illustrate the price development. Subsequently, I present the model. In Section 3.1, I derive the equilibrium before the existence of a student ticket. Section 3.2 then analyzes the new equilibrium with the student ticket. In Section 3.3, I discuss optimal policy. Section 4 wraps up and discusses some limitations of the analysis.

\section{The Student Ticket in Germany: An Overview}

The first city in Germany that had a "Semesterticket" was Darmstadt in October 1991. The ticket allowed the use of local buses for a price of $€ 7.16$ for the whole six months of the winter term of 1991/92. Other universities quickly followed. For instance, Bielefeld, Kaiserslautern and Kassel introduced it in 1992, and many others did so in the following years. Over time, additional transport services were added to the contracts, including regional trains, so that after a while the regions covered were often substantial. For example, in the state of North Rhine-Westphalia (NRW), most students nowadays have an NRW-Ticket that allows the use of all public transport in the state (with a population of 17.6 million). In October 2014, about 2.2 of the 2.6 million 
students in Germany studied at a university or college with a student ticket ${ }^{4}$

In public universities in most German states, all students are mandatory members of their Studierendenschaft, which means that they may elect a recognized representative committee and have to pay a membership fee. Its main task is political representation and engagement in the university administration, but it also commonly offers services like legal advice to students. Usually, where such a committee exists, it is the bargaining and contracting partner of public transport companies if a student ticket is introduced. The contract is then subject to a referendum among the students. It covers, for instance, price development, the bus and train lines for which the student ticket is valid, additional benefits like being allowed to take a bike on the bus, and the duration of the contract. Students of smaller colleges like Universities of Applied Science in the same city either negotiate separately, take part in the negotiations together with their counterparts from the large university, or are simply offered to accept the contract as it is, without additional bargaining.$^{5}$

In the state of Bavaria, there is no comparable recognized mandatory student representation, and in Baden-WÃ $\frac{1}{4}$ rttemberg there was none until 2012. There can still be student tickets at the universities in these states, and the contracting partner is then the local Studentenwerk organization, which is a semi-governmental institution providing student services. At some universities in other states, the Studentenwerk is the contracting partner, even though there is a student committee (e.g. in Leipzig). This institutional difference may change the exact pricing process, but the aim of providing a cheap, mandatory flat-rate ticket is the same. Additionally to the different models of contracting partners, there is a difference in student-ticket types. The typical "one-component" model allows a flat-rate usage of the public transport for a fixed obligatory payment, but there are also universities with a "two-component" ticket. The obligatory payment then either only gives access to cheaper tickets or allows restricted free access, for example in off-peak times (e.g. in Stuttgart; also see Weichbrodt, 2001; 4-5). In this article, I focus on the one-component type because it is the more common one and, arguably, the purer version of a politically-determined collective ticket.

The primary objective of introducing a student ticket is to reduce students' transportation expenses. Additional benefits are also mentioned in contracts, in court decisions or in the student committees' public statements. This includes, for instance, environmental-policy aims or parkingplace scarcity reduction (see BVerwG, 2000 or Weichbrodt, 2001; 17-19), but they are not comparably relevant.

A first reason why the student ticket is cheaper than usual monthly passes is that there are subsidies by regional government bodies. However, the public-transport companies would also receive these payments for ordinary, non-mandatory tickets for students, as they are subsidies for transporting young people to their place of education (Weichbrodt, 2001: 281). Thus, they cannot explain the price difference compared to transit passes offered to students who study at a university without an obligatory student ticket. This difference is indeed large. In Hamburg, for instance, the student ticket in the winter term of 2014/2015 costs $€ 160.50$ for six months. A transit pass offered to students without a mandatory student ticket is at least $€ 126.40$ per month (HVV, 2015a b).

Another relevant way of providing cheap access to transport for a majority of students is redistribution between the students. All students have to pay for the ticket, but while some use the public transport with or without a student ticket, others only use it because this ticket

\footnotetext{
${ }^{4}$ This number results from adding the institutions' student numbers. However, at some institutions, not all students may have the student ticket; for example, part-time students may be excluded. For additional explanations on the student numbers used in this section and on sources, see Appendix A

${ }^{5}$ In particular, this is often true for small private colleges that do not have a political student representation. The college management can make an agreement with the public-transport organization to adopt the student ticket. This decision, however, is rather a product-bundling decision instead of a political one.
} 
exists (implying a lower net benefit), and the rest do not even use the public transport with a student ticket, e.g. those who strongly prefer a car. The resulting conflict of interest has led to complaints in court. In their decisions, the courts did not explicitly refer to redistribution, but de facto discussed the different students' net-benefit differences, treating them as a justifiable side-effect of the ticket. In particular, the German Federal Administrative court ruled that the mandatory payments can be justified even if not all students want them, given that the price is not disproportionately high and is appropriate in relation to the benefits of cheaper public-transport usage, and that an overwhelming majority of students benefit from the lower cost of living. Concerning those students who do not use the ticket, the court referred to the option to use it and to the principle of solidarity (Solidargedanke in German); according to the opinion of the court, the German law views the group of students as a solidary group (Solidargemeinschaft), which may collectively offer services and apportion the costs among all of its members (BVerwG, 2000; supported by the German Federal High Court: BVerfG, 2000). Accordingly, student committees use the term of "solidarity" in their own texts (e.g. AStA Kassel, 2015), and refer to the mandatory one-component model as a solidary model (e.g. AStA Darmstadt, 2015; AStA TU, 2015: FAQ; AStA Mainz, 2015: FAQ).

In the following analysis, I ignore the directly redistributional motive, because I aim at analyzing the effects of a collective ticket in a situation in which it could, in principle, be beneficial for all students. This is impossible if the price-reduction relies only on enforced non-user payments. I therefore ignore heterogeneity with regard to students' intrinsic characteristics; for an analysis of this aspect, see Stähler (2000). Note, however, that my model predicts price increases, while heterogeneity may dampen this increase; if there are students who prefer a car so much that they still do not use the public transport with a student ticket, then they permanently subsidize the other students. If all student characteristics are exogenous - the case which is in direct contrast to my model - the price is permanently reduced. Thus, if we still observe strong price increases in student ticket prices over time, then this implies that price-increasing forces are strong enough to outweigh the redistributional dampener and other similar effects.

Discussing the Unlimited Access programs at US universities, Brown et al. (2001) also list a number of reasons for the programs' low costs. A reason that is not otherwise covered in this article is that of using excess transit capacity. The authors note that students are more likely than other people to travel at off-peak hours, so that they can fill empty seats in the bus. This explains low marginal cost of students' bus rides; it does not explain, however, why there are no regular, non-mandatory tickets offered to students - or anybody else - limited to off-peak times that are comparably cheap.

In this article, I focus on the remaining reason for low prices, namely, a reduction in the cost of public-transport provision due to the mandatory and thus guaranteed purchase of the ticket. Specifically, the student ticket eliminates some forms of transaction cost. Weichbrodt (2001: 171) argues that administration efforts are reduced, because the need for individual tickets disappears. Brown et al. (2001) list the cost of printing and selling individual transit passes, the reduced need for small cash transactions, and the reduced boarding time. Likewise, there is probably far less need for student-specific marketing, and fare evasion can be avoided, while at the same time there is less need for ticket control. Focusing on these transaction-cost reductions, I analyze the price and its dynamics under the most favorable circumstances, namely those in which the student ticket can in principle be a Pareto improvement. I then analyze the unintended side effects of the tickets that come about from individual adaptation even in this favorable case.

The model in Section 3 implies that these side-effects cause price increases after a period of adjustment. Before discussing the model, let us take a look at some data, so as to gain an understanding of the development of actually existing student ticket prices, and to consider 


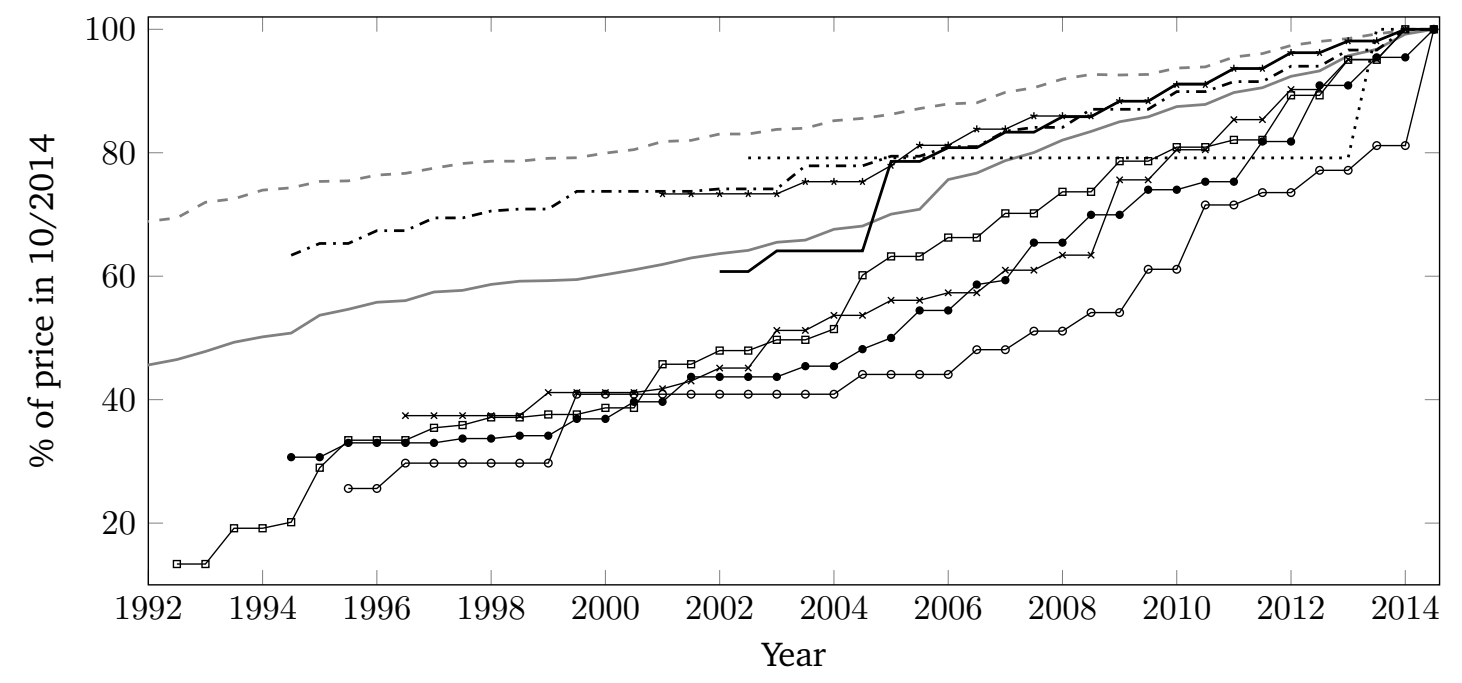

$$
-\cdots \mathrm{CPI}-\mathrm{CPI} P \mathrm{PT}-\mathrm{B} \cdots \cdots \mathrm{F}-\cdots \mathrm{H} \rightarrow \mathrm{K} \rightarrow-\mathrm{M} \rightarrow \mathrm{O} \rightarrow \mathrm{P} \rightarrow-\mathrm{R}
$$

Figure 1: Student-ticket price development of a sample of universities.

All prices are standardized to the price in October 2014. CPI PT is the consumer-price index for single tickets and day passes.

whether the alleged price increases are relevant. A central database for this does not exist. Below, I discuss the price development of a sample of universities, collected from university administrations, student committees, or public-transport companies. Data sources and summary statistics are provided in Appendix A.

The following discussion does not claim to be an exhaustive empirical evaluation, but merely an illustration. One reason is the lack of comparability between cities; the student ticket was introduced at different times under different circumstances, and, for instance, the political framework for the local public transport may be relevant for price development. The neglected aspects of the student ticket pointed out above are another reason, because they may operate differently in different cities. Additionally, the product whose price development is depicted may change in time. For instance, when the student ticket is introduced for the first time, it may allow the use of local buses. If it is subsequently extended to regional trains, the payments can often be separated to keep things comparable, but even then, some bus lines, for instance, may be added or dropped. Due to space limitations, I only discuss a number of cases. Of the available price series, those used are selected on the basis of institutional arrangements (student committees are the contract partner of the public-transport companies), type of student ticket (one-component model), reliability of the data, interpretability and comparability over time.

The price developments are graphed in Figure 1. To render price dynamics comparable, all prices are standardized. Each data point is the price in the respective term, relative to the price at the same university in the winter term of 2014/2015. For comparative purposes, the solid gray line in the figure referred to as "CPI PT" (for "public transport") depicts the price index for single tickets and day passes. It has an average annual inflation (AAI) rate of 3.6\% over the 23 years from October 1991 through October 2014, this month being chosen because German university terms usually start in October and April $\square^{6}$ The general consumer-price index is depicted as a gray

\footnotetext{
${ }^{6}$ This is higher than for other comparable indices; the index is chosen so as to avoid the student ticket price increases
} 
dashed line; its AAI is $1.74 \%$. Due to the standardization, we can see that a student ticket has been subject to greater inflation than the CPI PT over the whole time period, if its price curve has a lower value than the CPI PT curve in the term in which the student ticket was introduced. This is true for five of the series in the figure, and not for three of them. Let us first consider the latter ones.

In Hamburg $(H)$, a student ticket was introduced in October 1994. It allows use of the public transport in the metropolitan region of Hamburg. The ticket is available at a number of universities and colleges in Hamburg, the largest of which are the University of Hamburg (about 41,000 students), the University of Applied Sciences $(15,800)$, the Technical University $(6,600)$ and the HafenCity University $(2,400)$. When introduced, the price was $€ 101.75$, and reached $€ 160.50$ in October 2014 , implying a moderate increase of $2.31 \%$ per year.

In the much smaller city of Flensburg ( $F ; 84,000$ inhabitants), a student ticket was introduced in October 2002 for $€ 28.50$. It allows students of the University $(4,800)$ and the University of Applied Sciences $(4,100)$ to use local buses. The price remained constant until the contract was renegotiated in 2013 to $€ 36$, with the aim of keeping it at that level for two years, re-evaluating and then switching to an adjustment once every four years (Pohl, 2013). The price increase in 2013 implies an average increase of $1.97 \%$ per year over the 12 years of the student ticket's existence.

In Potsdam $(P)$, a student ticket has existed since April 2001. Students of the University (20,000 students), the University of Applied Sciences $(3,400)$ and the Film University of Babelsberg (600) may use the public transport not only in Potsdam, but in the entire state of Brandenburg (almost as large as Belgium, 2.45 million inhabitants) and in Berlin, which is surrounded by Brandenburg, but constitutes a separate state. The ticket is bargained with the public transport authority of Berlin and Brandenburg, VBB (Tagesspiegel, 2004). The AAI is 2.32\%.

We now consider cities in which the price increases of the student ticket were greater than those of the CPI PT. $B$ shows the price development for Berlin, where about 156,000 students of public and private universities and colleges have a student ticket. Student representatives of a number of large public universities - the largest of which are the Free University of Berlin (33,000 students), the Humboldt University $(32,000)$ and the Technical University $(31,000)$ - bargain a common price with the VBB (Gagiu, 2007) and several small private universities subscribe to the ticket subject to the same terms. The student ticket allows use of the public transport in Berlin and its immediate surroundings, which is a subset of the student ticket area of students in Potsdam. It was introduced in the summer term of 2002 for $€ 109$, while the ticket in Potsdam cost $€ 112$, and both tickets were $€ 115$ in April 2003. For 2005, the VBB demanded a price increase to $€ 141$, based on an expert assessment of the costs (Ibs, 2004). The difference to Potsdam was justified by the fact that students living in Berlin use the city's dense traffic system more often (Tagesspiegel, 2004). The proposed price led to rejections in referenda among the students. These referenda, however, were repeated and the ticket was accepted when it became clear that the price was a take-it-or-leave-it offer. This did not work everywhere; students of the Free University thus did not have a student ticket for one term, but accepted the price increase a term later (Lee and Rother, 2004). Over the entire period covered, the price increase was about $4 \%$ per year on average.

$K$ shows the development of the student ticket price at the University of Kassel (about 22,700 students), where such a ticket has existed since October 1992. It was introduced for a price of $€ 15.34$, allowing the use of local public transport. In 1995, when a public-transport organization covering a larger region was founded, the student ticket was extended, and the price increased to $€ 38.35$ (HNA, 1995). The ticket was further extended in 2009 , adding trains to neighboring regions. The time series in the figure is based on payments to the regional traffic authority of

appearing artificially high. For the other indices, see Appendix A 
Kassel, NVV, only. Payment for this part of the student ticket increased by $9.58 \%$ per year on average since October 1992 (5.94\% per year relative to October 1995). An increase from $€ 59$ to $€ 69$ in 2004 was explicitly justified on the basis of increased usage (HNA, 2004).

$M$ is the price development of the student ticket in Mainz. It is valid for students of the Johannes Gutenberg University of Mainz (34,000 students), the University of Applied Sciences $(5,000)$, the Catholic University of Applied Sciences $(1,200)$ and the small private European Management School. When introduced in October 1994, the student ticket covered only local traffic; regional traffic lines were added later, starting in 1995. The price development in the figure covers only payments to the local public-transport company, MVG, in order to provide a lower bound of price inflation, which is $6.09 \%$ per year.7 The higher price increases after contract renegotiations from 2004 onwards and from 2011 onwards were justified referring to an increased usage of public transport by the students (Stadtwerke Mainz, 2004, 2011).

$O$ is the development of the local-traffic component of the student ticket at the University of Osnabrück (11,800 students); payments to train companies are omitted from the time series for reasons of comparability. Starting at $€ 12.78$ in 1995, it has increased by $7.43 \%$ per year on average. The price increase in 1999 stems from an extension of the covered bus lines to the region surrounding the city (University of Osnabrück, 1999); the increases in 2010 and in 2014, by contrast, resulted from high student usage of the buses, which also led to the addition of a new bus line (NOZ, 2010; Stricker, 2014).

Finally, $R$ depicts the development of the student ticket of the University of Rostock $(14,000$ students), the Rostock University of Music and Theatre (500) and a department of the University of Applied Sciences Wismar located in Rostock. The ticket exists since October 1996 and allows use of the city's local public transport. Then $€ 30.68$, the price has increased by $5.61 \%$ per year on average. In negotiations in 2014 resulting in an increase from $€ 82$ to $€ 99$ in 2015 , the transport company argued that student public-transport usage had increased strongly (Hebben, 2014; OZ, 2014).

To summarize the various depictions, while there are clearly cities where the student ticket has a price inflation below that of a comparable index, and in Flensburg, it even remained the same for a long time after introduction, a number of cases reveal a pattern of marked price increases in contract renegotiations, due to increased public-transport usage. While the logic of a flat-rate implies such an increase, the interesting point is that the flat-rate pricing is chosen by the students themselves. In the following section, I present a model to explain why a majority of them may decide this way.

\section{The Model}

\subsection{The Situation without a Student Ticket}

Consider a student whose utility in period $t$ is

$$
u\left(S, F_{t}\right)=\alpha \ln (S)+F_{t},
$$

where $S$ is the size of the student's apartment and $F$ is leisure time. The student's budget is $Y_{t}+w L_{t}=\gamma S+k_{t} D$; in the following, I drop the time index where no ambiguities arise. On the left-hand side, $Y$ is the part of available income that is independent of working, $w$ is the wage and $L$ is the student's labor supply. On the right-hand side, $\gamma S$ is the rent for the apartment, $D$ is the distance from the student's place of residence to the university, and $k$ are marginal monetary

\footnotetext{
${ }^{7}$ However, since April 2013, a bike-rental system has been included.
} 
costs of commuting. Assuming that the university is more or less located in the city center, the rent per square meter decreases with the distance to the university: $\gamma=D^{-\sigma}$. This implies

$$
Y_{t}+w L_{t}=D^{-\sigma} S+k_{t} D
$$

The time budget is normalized to unity, so that we have

$$
L_{t}=1-F_{t}-x D,
$$

where $x$ is the time for commuting a unit of distance (so that $1 / x$ is speed). Substituting (2) and (3) into (1) yields utility in $t$ as a simplified location-dependent Alonso (1964) utility function, depending on apartment size, distance, income and costs of commuting:

$$
u_{t}\left(S, D, Y_{t}, k_{t}\right)=1+\alpha \ln (S)-x D+\frac{1}{w}\left[Y_{t}-k_{t} D-D^{-\sigma} S\right] .
$$

Every student is at the university for three periods. Her objective is intertemporal expected utility. Due to the finite horizon, we can neglect discounting. To simplify the formulas, I define intertemporal utility as the average utility per period. Letting $E_{t}$ denote expectations just before $t$, the student's intertemporal expected utility then is:

$$
\begin{aligned}
U_{t}= & \frac{1}{3} E_{t}\left[u\left(S, D, Y_{t}, k_{t}\right)+u\left(S, D, Y_{t+1}, k_{t+1}\right)+u\left(S, D, Y_{t+2}, k_{t+2}\right)\right] \\
= & 1+\alpha \ln (S)-x D-\frac{1}{w} D^{-\sigma} S \\
& +\frac{1}{3 w} E_{t}\left[Y_{t}+Y_{t+1}+Y_{t+2}-\left(k_{t}+k_{t+1}+k_{t+2}\right) D\right] .
\end{aligned}
$$

The student optimizes (5) stepwise. Firstly, she chooses the distance $D$ and the apartment size $S$ before her first period starts. Both cannot be changed afterwards, which is a simplified way of incorporating the fact that moving is costly. Secondly, she chooses the cheapest mode of transport in each $t$. There are two modes of transport: the automobile, $a$, and the public transport that may include buses and trains but, for brevity, it is referred to as "bus", $b$, in the following. Both have the same $x$. The monetary costs of commuting are $k_{a}$ and $k_{b} . k_{a}$ is exogenous; $k_{b}$ is chosen by the bus company in $t$ (as derived below). I assume that switching costs are zero, so that each student can change to the cheapest mode of transport. This makes the automobile to be something like a cab, but its sole purpose in this model is to be a substitute for the bus and thus determine the maximum willingness to pay. The student's commuting cost then is determined by $k_{t}=\min \left(k_{a}, k_{b, t}\right)$. $^{8}$

Optimizing (5) as described yields the optimal place of residence and apartment size, depending on the expected price of commuting, averaged for the three periods:

$$
\begin{aligned}
D^{*}\left(E_{t}\left[k_{t}+k_{t+1}+k_{t+2}\right] / 3\right) & =\frac{\alpha \sigma}{x+\frac{1}{3 w} E_{t}\left[k_{t}+k_{t+1}+k_{t+2}\right]}, \\
S^{*}\left(E_{t}\left[k_{t}+k_{t+1}+k_{t+2}\right] / 3\right) & =\alpha w\left[D^{*}\left(E_{t}\left[k_{t}+k_{t+1}+k_{t+2}\right] / 3\right)\right]^{\sigma} .
\end{aligned}
$$

\footnotetext{
${ }^{8}$ Total transport costs per unit of distance are $x+k_{t} / w$. If the speed of different modes of transport were different, then we would have $x_{a}+k_{a} / w$ for the automobile and $x_{b}+k_{b, t} / w$ for the bus, so that a student would choose the bus as long as $k_{b, t} \leq w\left(x_{a}-x_{b}\right)+k_{a}$. This does not matter for the model in which all students have the same opportunity costs of time, but we can see why a $w$ heterogeneity would lead to a heterogeneity in the chosen vehicle. Moreover, with different $x$ values, the alternative mode of transport could be thought of as a bike, even though bikes have practically no pecuniary marginal costs.
} 
Thus, if the expected cost of commuting is lower, a student will live further away from the center and have a larger apartment. For compactness, I (re-)define optimized utility in period $t+\tau$, where $\tau \in\{0,1,2\}$, without the constant terms,

$$
\begin{aligned}
& v_{t+\tau}\left(Y_{t+\tau}, k_{t+\tau} ; E_{t}\left[k_{t}+k_{t+1}+k_{t+2}\right] / 3\right) \\
& \equiv u_{t+\tau}\left(S^{*}\left(E_{t}\left[k_{t}+k_{t+1}+k_{t+2}\right] / 3\right), D^{*}\left(E_{t}\left[k_{t}+k_{t+1}+k_{t+2}\right] / 3\right), Y_{t+\tau}, k_{t+\tau}\right) \\
& \quad-[1-(1+\sigma) \alpha+\alpha \ln (w \alpha)],
\end{aligned}
$$

which yields:

$$
\begin{aligned}
& v_{t+\tau}\left(Y_{t+\tau}, k_{t+\tau} ; E_{t}\left[k_{t}+k_{t+1}+k_{t+2}\right] / 3\right) \\
& =\alpha \sigma \ln \left(D^{*}\left(E_{t}\left[k_{t}+k_{t+1}+k_{t+2}\right] / 3\right)\right)+\frac{Y_{t}}{w}+\frac{\alpha \sigma}{w} \frac{\frac{1}{3} E_{t}\left[k_{t}+k_{t+1}+k_{t+2}\right]-k_{t+\tau}}{x+\frac{1}{3 w} E_{t}\left[k_{t}+k_{t+1}+k_{t+2}\right]} .
\end{aligned}
$$

The supply side of public transport is a monopolistic bus company. For simplicity, I assume that it has constant marginal costs $\bar{k} \in\left[0, k_{a}\right)$ of transporting a student for a unit of distance. Thus, if a student lives at distance $D^{*}\left(E_{t}\left[k_{t}+k_{t+1}+k_{t+2}\right] / 3\right)$, the bus company's profit from transporting that student in $t$ is

$$
\pi_{t}=\left(k_{b}-\bar{k}\right) D^{*}\left(E_{t}\left[k_{t}+k_{t+1}+k_{t+2}\right] / 3\right)-c,
$$

where $c>0$ are per-student transaction costs like marketing and ticket control. To maximize profit, the bus company sets the ticket price to the maximum willingness to pay, which is determined by the alternative mode of transport. Assuming that students choose the bus when indifferent, this implies $k_{b, t}=k_{a}$ for all $t$.

When choosing their apartment size and distance, students will rationally anticipate this price: $E_{t}\left[k_{t+\tau}\right]=k_{t+\tau}=k_{a}$ for $\tau \in\{0,1,2\}$. Thus, (6) becomes

$$
\begin{aligned}
D^{*}\left(k_{a}\right) & =\frac{\alpha \sigma}{x+k_{a} / w}, \\
S^{*}\left(k_{a}\right) & =\alpha w\left[D^{*}\left(k_{a}\right)\right]^{\sigma},
\end{aligned}
$$

and, assuming a constant income $Y_{t+\tau}=y$ for $\tau \in\{0,1,2\}$, (8) is

$$
v_{t+\tau}\left(y, k_{a} ; k_{a}\right)=\alpha \sigma \ln \left(D^{*}\left(k_{a}\right)\right)+\frac{y}{w} .
$$

With $N$ being the number of students, the bus company's profit then is

$$
\Pi_{t}=N \pi_{t}=N\left[\left(k_{a}-\bar{k}\right) D^{*}\left(k_{a}\right)-c\right]
$$

in every $t$. To make the situation described in the model relevant, I assume the firm to operate profitably, which requires that $c$ is bounded above by:

$$
\left(k_{a}-\bar{k}\right) D^{*}\left(k_{a}\right) \geq c .
$$

\subsection{The Student Ticket}

Suppose that until $t=0$, there has been an equilibrium as described in the previous section. Period $t=1$ starts the same way. But then within that period, someone proposes to establish a mandatory flat-rate ticket for all students, the "student ticket", which implies that all students 
pay a fixed price $P$ and then may use the public transport for free. Thus, from their perspective, the only variable cost of commuting would be the opportunity costs of time. The argument for introducing the ticket is to reduce costs related to individual ticket purchases. By this, transaction costs are assumed to be reduced from $c$ to zero.

I now derive under which circumstances such a ticket will come to exist, how its price develops and which impact it has on the students' utility. To do so, I make an assumption about the composition of the student population. It consists of three cohorts. In each period $t$, one third of the students are "new" $(n)$, which means that they are in their first period of studying, one third are "old" $(o)$, so they are in their third period, and one third are in the "middle" $(m)$, so they are in their second period. The order of moves is the following in each $t$. Firstly, new students choose distance $D$ and apartment size $S$. Secondly, the students' representatives and the bus company bargain a ticket price $P_{t}$, which has to be accepted by referendum afterwards. If it is not accepted, each student has to pay the usual ticket price, which is $k_{a}$ as above. (Finally, given the ticket and the apartment, each student chooses her labor supply, which is, as in the previous section, a residual.)

The solution concept for this interaction is to determine a subgame-perfect equilibrium for each period. Each new student chooses her place of residence on the first stage, taking the behavior of all other new students - and thus, the students' average distance to the university as given. On the second stage the student representatives and the bus company bargain a price for the ticket. If there is a price to which both agree, the ticket is introduced for the respective period. The upper limit for this price is determined by the referendum on the third stage.

By this order of moves, bargaining always takes place over the ticket for the current period only. When it does, the place of residence (of all students) is already determined. Thus, the existence of a student ticket has no effects on future periods. What does have an effect, however, is the expectation of whether a student ticket will be established in the future, because this expectation determines the place of residence.

Suppose that students who choose their place of residence just before $t$ expect the student ticket to exist with probability $\rho_{t+\tau}$ in period $t+\tau$. Expectations are formed rationally, so that $\rho_{t+\tau}$ is the correct probability, determined by the structure of the game. Because a student ticket implies zero marginal (monetary) transportation costs, the expected marginal transportation costs for period $t+\tau$ are $E_{t}\left[k_{\tau}\right]=\left(1-\rho_{t+\tau}\right) k_{a}$. By (6a), the distance of students who are new in $t$ is

$$
\begin{aligned}
D_{t}^{n} & \equiv D^{*}\left(\left(3-\rho_{t}-\rho_{t+1}-\rho_{t+2}\right) k_{a} / 3\right) \\
& =\frac{\alpha \sigma}{x+\frac{1}{3 w}\left(3-\rho_{t}-\rho_{t+1}-\rho_{t+2}\right) k_{a}} .
\end{aligned}
$$

Due to the cohort structure, $D_{t}^{n}=D_{t+1}^{m}=D_{t+2}^{o}$.

The choice of location is determined by the expectation about the student ticket's existence, but the actual transportation costs and income are determined by whether it indeed exists. Period utility (8) becomes

$$
\begin{aligned}
& v_{t+\tau}\left(y-P_{t+\tau}, k_{t+\tau} ;\left(3-\rho_{t}-\rho_{t+1}-\rho_{t+2}\right) k_{a} / 3\right) \\
& =\alpha \sigma \ln \left(D^{*}\left(\left(3-\rho_{t}-\rho_{t+1}-\rho_{t+2}\right) k_{a} / 3\right)\right) \\
& \quad+\frac{y-P_{t+\tau}}{w}+\frac{\alpha \sigma}{w} \frac{\frac{1}{3}\left(3-\rho_{t}-\rho_{t+1}-\rho_{t+2}\right) k_{a}-k_{t+\tau}}{x+\frac{1}{3 w}\left(3-\rho_{t}-\rho_{t+1}-\rho_{t+2}\right) k_{a}} .
\end{aligned}
$$

for $\tau \in\{0,1,2\}$, where $k_{t+\tau}=0$ and $Y_{t+\tau}=y-P_{t+\tau}$ if a student ticket exists in $t+\tau$, and $k_{t+\tau}=k_{a}$ and $Y_{t+\tau}=y$ if it does not. Note that $t$ is the period in which the respective student was new. 
The only exception to the assumption that the place of residence is chosen based on correct probabilities are students who chose their place of residence up to period $t=1$. By assumption, they did not have anything like a student ticket in mind, so that

$$
D_{0}^{n}=D_{1}^{n}=D^{*}\left(k_{a}\right)=\frac{\alpha \sigma}{x+k_{a} / w},
$$

is their place of residence and their utility is

$$
\begin{aligned}
& v_{t+\tau}\left(y-P_{t+\tau}, k_{t+\tau} ; k_{a}\right) \\
& =\alpha \sigma \ln \left(D^{*}\left(k_{a}\right)\right)+\frac{y-P_{t+\tau}}{w}+\frac{\alpha \sigma}{w} \frac{k_{a}-k_{t+\tau}}{x+k_{a} / w} .
\end{aligned}
$$

for $t \in\{0,1\}$.

For a student ticket to be attainable, there must be a price between the minimum price that the bus company is willing to accept, $\breve{P}_{t}$, and the maximum price that the majority of students is willing to pay, $\hat{P}_{t}$. Consider $\check{P}_{t}$ first. To derive the bus company's profit without the ticket, we have to generalize (12) to take into account that different cohorts of students may live in different places. Students who are new in period $t$ have chosen $D_{t}^{n}$, while those who are old live at $D_{t}^{o}=D_{t-2}^{n}$ and the middle cohort lives at $D_{t}^{m}=D_{t-1}^{n}$. Then the company's profit without a student ticket is

$$
\Pi_{t}=N\left[\left(k_{a}-\bar{k}\right) \frac{1}{3}\left(D_{t}^{n}+D_{t}^{m}+D_{t}^{o}\right)-c\right] .
$$

With the ticket, profit is $\Pi_{t}=N\left[P_{t}-\bar{k} \frac{1}{3}\left(D_{t}^{n}+D_{t}^{m}+D_{t}^{o}\right)\right]$. The bus company must not be worse off if a student ticket is established, so

$$
\check{P}_{t}=k_{a} \frac{D_{t}^{n}+D_{t}^{m}+D_{t}^{o}}{3}-c .
$$

A student will prefer to have a student ticket in $t+\tau$ if the utility with it is higher than the utility without it, which boils down to the difference in payments necessary for commuting in each case. Because a proposed price has to be accepted by referendum after bargaining, the relevant limit is the willingness to pay of the median student, which is determined by the distance of her apartment to the university. I now conjecture that the distance of the old students is never higher than that of the middle students, and that of the middle students is never higher than that of the new ones; I later return to the question of whether this condition is fulfilled. Therefore, the student majority's willingness to pay, $\hat{P}_{t}$, is determined by the commuting costs of the middle cohort:

$$
\hat{P}_{t}=k_{a} D_{t}^{m}
$$

Thus, if

$$
\hat{P}_{t} \geq \check{P}_{t} \Leftrightarrow c \geq \frac{2}{3}\left(\frac{D_{t}^{n}+D_{t}^{o}}{2}-D_{t}^{m}\right) k_{a}
$$

holds as a strict inequality, there are potential gains for both the bus company and the student majority to bargain a student ticket. If it holds as an equality, they are indifferent about it. If the weak inequality does not hold, there will be no such ticket because both sides of the bargain are better off with individual tickets than with an attainable collective ticket. This is true, for 
instance, if new students live so far away from the center that the old and middle cohorts are not willing to share their commuting costs. Equation (21) says that either the median student's willingness to pay must be higher than the company's average transportation revenue without a student ticket in that period, or the saved transaction costs must be high enough to compensate for the difference.

For the student ticket's existence and for the choice of the place of residence, it does not matter how the gains from it are shared between the students and the bus company (assuming that they at least get a small part of the gains or agree if indifferent). I thus discuss these points first and price determination afterwards. Before $t=1$, by assumption, nobody has expected a student ticket, so that all students live at the same distance to the center, which is given by (10a), and in this case, (21) is definitely fulfilled. The development in $t \geq 2$ can be characterized as follows.

Proposition 1 (Equilibrium with a Student Ticket). Suppose that transaction costs are high in the following sense:

$$
c>\frac{1}{3} k_{a}\left(D^{*}(0)-D^{*}\left(k_{a}\right)\right) \Leftrightarrow c>\frac{\alpha \sigma}{3}\left(\frac{1}{x}-\frac{1}{x+k_{a} / w}\right) k_{a} .
$$

Then the unique subgame-perfect equilibrium for $t \geq 2$ is a pure-strategy equilibrium in which a student ticket exists with certainty and new students always choose $D_{t}^{n}=D^{*}(0)$. The middle-cohort students always live at median distance, so that (20) is valid.

Proof. See Appendix B.

Proposition 1 tells us that if transaction costs are high enough, then there will be a student ticket with certainty. In characterizing the effects of the ticket, I focus on this case in order to avoid an involved discussion of a mixed-strategy equilibrium. Moreover, the potential gains of a student ticket are highest if high transaction costs can be saved.

If the ticket exists, I assume that the bargained price is a compromise between the students' willingness to pay and the lowest price that the bus company would accept:

$$
P_{t}=\beta k_{a} D_{t}^{m}+(1-\beta)\left(k_{a} \frac{D_{t}^{n}+D_{t}^{m}+D_{t}^{o}}{3}-c\right),
$$

where $\beta \in(0,1)$ represents the bus company's bargaining power.

We know the place of residence for the student cohorts that were new up to $t=1$ from (17), and it can be calculated for all further student cohorts by (14), where we know from Proposition 1 that $\rho_{t}=1$ for all $t \geq 2$. Using this, the price of the student ticket follows from (23). The development of both is presented in Table 1 .

Up to $t=0$, the $D$ choice takes the full cost of commuting into account. In $t=1$, a student ticket is proposed and accepted, but nobody had expected it in $t=0$. Thus, $D_{1}^{n}$ is still chosen as before, and the ticket is advantageous for all students because it helps saving transaction costs. From $t=2$ on, new students anticipate the student ticket and choose their place of residence accordingly. This lets the price increase by increasing the lowest price that the bus company would be willing to accept, $\check{P}_{2}$. However, those students who have chosen their place of residence before $t=2$ are decisive in $t=1$ and $t=2$; their alternative expenditure for regular tickets is the upper price limit, and they live nearer to the university than new students do. Thus, all students still pay less for the student ticket than they would pay without it.

In $t=3$, the new students from $t=2$ have become the middle cohort. The price increases both because the student majority is willing to pay more, and because average transportation 
Table 1: Development of the students' place of residence and the student ticket price.

\begin{tabular}{ccccc}
$t$ & $D_{t}^{o}$ & $D_{t}^{m}$ & $D_{t}^{n}$ & $P_{t}$ \\
\hline \hline 0 & $D^{*}\left(k_{a}\right)$ & $D^{*}\left(k_{a}\right)$ & $D^{*}\left(k_{a}\right)$ & $/$ \\
\hline 1 & $D^{*}\left(k_{a}\right)$ & $D^{*}\left(k_{a}\right)$ & $D^{*}\left(k_{a}\right)$ & $k_{a} D^{*}\left(k_{a}\right)-(1-\beta) c$ \\
\hline 2 & $D^{*}\left(k_{a}\right)$ & $D^{*}\left(k_{a}\right)$ & $D^{*}(0)$ & $k_{a} D^{*}\left(k_{a}\right)$ \\
& & & & $-(1-\beta)\left[c-\frac{1}{3} k_{a}\left[D^{*}(0)-D^{*}\left(k_{a}\right)\right]\right]$ \\
\hline 3 & $D^{*}\left(k_{a}\right)$ & $D^{*}(0)$ & $D^{*}(0)$ & $k_{a} D^{*}(0)$ \\
& & & & $-(1-\beta)\left[c+\frac{1}{3} k_{a}\left[D^{*}(0)-D^{*}\left(k_{a}\right)\right]\right]$ \\
\hline$\geq 4$ & $D^{*}(0)$ & $D^{*}(0)$ & $D^{*}(0)$ & $k_{a} D^{*}(0)-(1-\beta) c$
\end{tabular}

The distance is given by (14) as $D^{*}\left(k_{a}\right)=\sigma \alpha /\left(x+k_{a} / w\right)$ and $D^{*}(0)=\sigma \alpha / x$. For the price, see equation (23).

costs have further increased. The old students that live nearer to the university have become a minority so that they are not relevant for the upper price limit anymore. If the transaction cost savings or the students' bargaining power are low, then the majority may agree to a price that puts the old student cohort in a worse position, compared to the situation without a student ticket. By the values from Table 1 , this is true if

$$
P_{3}>k_{a} D^{*}\left(k_{a}\right) \Leftrightarrow k_{a} \frac{1}{3}[2+\beta]\left[D^{*}(0)-D^{*}\left(k_{a}\right)\right]>(1-\beta) c .
$$

For instance, even if the students have all bargaining power $(\beta=0)$, the old-student cohort is worse off if $c<\frac{2}{3} k_{a}\left[D^{*}(0)-D^{*}\left(k_{a}\right)\right]$ which is possible even if condition (22) is fulfilled. Note that the students in $t=1$ cannot avoid becoming a minority by voting against the ticket in $t=1$. This would put them in a worse position in $t=1$, but their position later would not improve; there is no direct influence of the decision to introduce a ticket in any period on the existence of the ticket in later periods.

Finally, in $t=4$ and all later periods, all students have optimized their place of residence anticipating a student ticket. Thus, transportation costs are on a new equilibrium level. For a utility comparison between the new and the old equilibrium, we also have to take apartment sizes into account. Using the values from Table 1 in (15), we can calculate the utility difference between students in $t=4$ and $t=0$ :

$$
\begin{aligned}
& v_{4}\left(y-P_{4}, 0 ; 0\right)-v_{0}\left(y, k_{a} ; k_{a}\right) \\
& =\alpha \sigma\left[\ln \left(D^{*}(0)\right)-\ln \left(D^{*}\left(k_{a}\right)\right)\right]-\frac{k_{a} D^{*}(0)-(1-\beta) c}{w} \\
& =\alpha \sigma\left[\ln \left(1+\frac{k_{a} / w}{x}\right)-\frac{k_{a} / w}{x}\right]+\frac{(1-\beta) c}{w} .
\end{aligned}
$$

If students have no bargaining power so that they do not benefit from the saved transaction costs $(\beta=1)$, then this is definitely negative. The reason is that in the new equilibrium, nobody internalizes the full costs of living far away from the center.

Thus, all student cohorts benefit from a student ticket in equilibrium if transaction cost savings and bargaining power are large enough to outweigh the increased transportation costs. 
Otherwise, they are worse off in the new equilibrium, compared to a hypothetical situation in which the student ticket would not have been introduced in the first place. However, even if students in the new equilibrium are worse off, they will always agree to the continuation of the student ticket because it is beneficial given their place of residence, and new students will choose a place of residence that is too far from the center because they correctly anticipate that the student ticket will still exist in the future.

\subsection{Optimal Policy}

The development of the student ticket price is determined by the fact that it is always ex-post rational to vote in favor of it, and that anticipating this behavior changes the incentives. Things would change if the old and middle cohorts of $t=1$ could commit to voting against the student ticket in $t=2$ if its price were higher than $k_{a} D^{*}\left(k_{a}\right)-(1-\beta) c$. A member of the new cohort could then anticipate that her only equilibrium location is $D^{*}\left(k_{a}\right)$ and the gains from the collective ticket would remain identical to those in $t=1$. Such an announcement at the end of $t=1$, however, would not be time-consistent. Having a student ticket for the bargained price is always ex-post optimal for the majority.

Therefore, consider a (local) government at the beginning of $t=1$. Someone proposes to introduce a student ticket as described above. The government knows that the new students will choose their place of residence in anticipation of the ticket in the future. Which policy should it choose to attain an efficient allocation?

The situation before the student ticket is inefficient for two reasons. Firstly, the ticket price is $k_{a}$, even though the marginal transportation costs are only $\bar{k}<k_{a}$, due to monopolistic price discrimination. Capital costs might be a reason for this, but indivisibilities make it plausible that market power still directly distorts the price. Due to this distortion, students live inefficiently close to the city center. Secondly, there are transaction costs that can be saved by introducing a collective ticket. Nonetheless, the student ticket is not an efficient solution, because it makes students choose their location as if the marginal cost of commuting were zero, while in fact it is still $\bar{k}$.

Thus, an efficient policy would be to allow students and the company to bargain over the ticket, but to make new students choose an efficient place of residence, which reflects the real marginal costs of commuting, $D^{*}(\bar{k})$. This is not as far away as $D^{*}(0)$, so that, following the logic of Proposition 1 , this distance makes a bargain feasible; both the bus company and the old and middle cohorts will agree.

Theoretically, $D^{*}(\bar{k})$ could be attained in different ways. One way is a similar kind of commitment that is discussed above for the old and middle cohorts; the government could announce not allowing a student ticket if it is more expensive than $k_{a} D^{*}(\bar{k})-(1-\beta) c$. This has to be announced ex-ante and enforced ex-post, however, so that in the political process, it might not be certain whether the government will stick with the announcement.

Other ways would entail a penalty tax on distance, or forbidding students to live further away from the center than $D^{*}(\bar{k})$. While these possibilities are merely theoretical, a more plausible possibility is to change relative prices the other way round, namely by building subsidized student dorms at $D^{*}(\bar{k})$ or by subsidizing living at this distance. In the latter case, the subsidy would have to be designed in such a way so as to preserve the relative price of an apartment per square meter. In this way, the place-of-residence decision is corrected, without distorting the choice of apartment size. Assume that student apartments are subsidized with a payment $s(D)$, so that a student's rent is $D^{-\sigma} S-s(D)$. Adjusting equation (5) with this subsidized rent function and zero marginal payments for commuting, the student's marginal cost of distance is $x+D^{-\sigma} S-s^{\prime}(D)$. Marginal social costs, on the other hand, are $x+D^{-\sigma} S+\bar{k}$. Thus, any subsidy system which 
reduces the subsidy according to the distance from the center as much as transportation costs increase, $s^{\prime}(D)=-\bar{k}$, leads to an efficient allocation.

\section{Conclusions}

We have seen how a mandatory flat-rate student ticket for public transport may, on the one hand, be useful because it reduces transaction costs, but on the other hand, it leads to an inefficient choice of location. Students who anticipate such a ticket will live further away from the city center exactly because they face zero marginal (pecuniary) costs of commuting. When a student ticket is proposed and introduced for the first time, it will be cheaper than individual tickets - but once students optimize taking the flat-rate ticket into account, the ticket price rises. If the saved transaction costs and student bargaining power are high enough, the ticket is still beneficial. By contrast, if the student bargaining power is very low, they are worse off than they would be if the flat-rate ticket had never been introduced. But even if the students do not prefer the new equilibrium situation to the old one, the ticket is self-sustaining; having already chosen their place of residence, students accept the expensive ticket.

However, forbidding a student ticket is also not efficient. Transaction cost savings are not realized and marginal commuting costs may be too high. Instead, optimal policy consists, among other possibilities, of accepting the bargained ticket, but at the same time providing incentives to students to live at an efficient distance - for example by offering subsidized student dorms there.

In Section 2, we have considered the price development of the student ticket in eight cities. Five of them exhibit a price development as it would be expected on the basis of the model in this article: There were comparably strong price increases and public-transport companies justified them by referring to increased usage by the students; in the end, the students accepted the higher prices, hard negotiations and reluctance notwithstanding.

Clearly, the remaining three cities had a price inflation below that of a comparable price index and, additionally, the student ticket prices are still low compared to regular transit passes. This points out that a number of aspects are missing in the model. To get a complete picture, it would be necessary to consider student heterogeneity, modal choice, and local circumstances like, for instance, the influence of local policy. If public-transport capacity is underutilized, cost increases over time may be small: 9 and if students strongly prefer to live in certain neighborhoods, the free usage of the public transport will possibly not have much of an influence on this choice. Finally, the effects of a student ticket that is valid for local buses only may be different from those that allow the use of regional trains throughout the state. It would thus be interesting to extend the case studies to take this difference into account. Some students may be inclined to continue living with their parents if commuting is cheap enough, including some who would otherwise not have studied at all. All these aspects have been deliberately left out of the model to focus on the dynamics of price, choice of abode, and the development of the relative advantage of the student ticket.

Note that there are also aspects left out of the model that would imply further cost and price increases. In particular, my model does not cover leisure-time trips. Fare-free public transport will certainly increase the number of such trips and therefore imply higher costs. The main reason for ignoring this in the model is the fact that both bargaining parties would anticipate this effect and therefore the public transport company would simply demand a higher price for introducing the student ticket. If the bargaining parties would have myopic expectations, however, and students first have to realize the benefits of fare-free bus rides, then price increases may come as an unpleasant surprise.

\footnotetext{
${ }^{9} \mathrm{I}$ thank an anonymous reviewer for raising this point.
} 
I have analyzed the effects of a flat-rate ticket for student tickets, on the one hand, because these tickets exist widely at German universities and their equilibrium effects are unclear a priori. On the other hand, they offer a model framework in which to analyze the principle of fare-free usage of the public transport for entire cities, paid for by taxes or other mandatory contributions. These policy proposals are currently being discussed in a number of cities. In doing so, a number of the aspects that I have ignored in the model should be taken into account. For instance, students are a relatively small part of the population, so that a partial-equilibrium analysis is sufficient in my model. By contrast, modeling the effect of fare-free transport on entire cities would suggest adding the supply side of the housing market to the model. Modal choice and capacities should be modeled explicitly, not least because of the second-best choices in urban policy, often balancing overcrowding in public transport on the one hand and road congestion on the other. Additionally, for choosing the policy of an entire city, heterogeneity becomes important and distributional effects should explicitly be taken into account. The basic trade-off implied by the model, however, is likely to be the same as in the case of a student ticket; transaction-cost savings have to be balanced against the adverse side-effects that stem from distorted incentives.

\section{A Price-Data Sources and Average Annualized Inflation}

All data on student numbers in Section 2 refer to the winter term 2013/2014; they are provided by destatis (2014). A search on university and college websites and a comparison to destatis (2014) reveals that about 1.78 million students study at institutions with a one-component student ticket, and about 0.45 million have a two-component student ticket. The source for the scope of the student ticket in Darmstadt in 1991 is AStA Darmstadt (2015); price data was provided by the AStA (student committee) of the Technical University of Darmstadt by email. A table with the data used in this article and some additional time series can be obtained from the author. The following table summarizes some basic statistics and the data sources of the time series shown in Figure 1. Data sources are denoted in italic. Where only an institution, e.g. the respective AStA, is listed, the data was provided by email.

\begin{tabular}{|c|c|c|c|}
\hline Series & Explanation & $\begin{array}{l}\text { Start: } \\
\text { Month, } \\
\text { Price }\end{array}$ & $\begin{array}{c}\text { AAI } \\
\text { AAI PT }\end{array}$ \\
\hline \multirow[t]{2}{*}{ CPI } & Consumer Price Index & $1991 / 10$ & $1.74 \%$ \\
\hline & destatis (2015), series 61111-0002 & - & $3.60 \%$ \\
\hline CPI & Price index for single tickets and day passes & $1991 / 10$ & $3.60 \%$ \\
\hline PT & $\begin{array}{l}\text { destatis } \\
\text { CC0735011000) }\end{array}$ & - & $(3.60 \%)$ \\
\hline \multirow[t]{2}{*}{ B } & Student ticket price in Berlin & 2002/04 & $4.07 \%$ \\
\hline & $\begin{array}{l}\text { RefRat HU (2015); } \\
\text { Berlin (2001) }\end{array}$ & $€ 109$ & $3.68 \%$ \\
\hline \multirow[t]{2}{*}{$\mathrm{F}$} & Student ticket price in Flensburg & $2002 / 10$ & $1.97 \%$ \\
\hline & AStA Flensbur & $€ 28.50$ & $3.76 \%$ \\
\hline \multirow[t]{2}{*}{$\mathrm{H}$} & Student ticket price in Hamburg & $1994 / 10$ & $2.31 \%$ \\
\hline & $H V V(2015 b)$ & $€ 101.75$ & $3.45 \%$ \\
\hline \multirow[t]{2}{*}{$\mathrm{K}$} & Student ticket price in Kassel (regional-traffic part) & $1992 / 10$ & $9.58 \%$ \\
\hline & Administration of the University of Kassel & $€ 15.34$ & $3.54 \%$ \\
\hline \multirow[t]{2}{*}{$\mathrm{M}$} & Student ticket price in Mainz (local-traffic part) & $1994 / 10$ & $6.09 \%$ \\
\hline & $\begin{array}{l}\text { AStA of the Johannes Gutenberg University of Mainz; } \\
\text { Mainzer Verkehrsgesellschaft (MVG) }\end{array}$ & $€ 33.75$ & $3.45 \%$ \\
\hline
\end{tabular}




\begin{tabular}{clcc} 
& & Start: & \\
Series & Month, & AAI \\
& Explanation & Price & AAI PT \\
\hline \hline $\mathrm{O}$ & Student ticket price in Osnabrück (local-traffic part) & $1995 / 10$ & $7.43 \%$ \\
& AStA of the University of Osnabrück & $€ 12.78$ & $3.23 \%$ \\
$\mathrm{P}$ & Student ticket price in Potsdam & $2001 / 04$ & $2.32 \%$ \\
& AStA of the University of Potsdam & $€ 111.97$ & $3.62 \%$ \\
$\mathrm{R}$ & Student ticket price in Rostock & $1996 / 10$ & $5.61 \%$ \\
& Administration of the University of Rostock & $€ 30.68$ & $3.27 \%$
\end{tabular}

$A A I$ is the average annual inflation of the respective price until October 2014; for the CPI measures, the AAI refers to the time span 1991/10-2014/10. For each series, AAI PT is the AAI of the CPI PT index in the respective period for comparison. Other price indices in the German Federal Statistical Office's database destatis (2015) similar to CPI PT are: Tickets for young people in education (Zeitkarte Verbundverkehr, Ausbildungstarif; code CC0735013100; available since 2005; AAI since then: 3.18\%); short-distance train tickets (CC0731031200; available since 1995; AAI: 3.13\%); monthly ticket (CC0735015000; exists for the whole time span; AAI: 3.57\%).

Of those universities that answered the data request, some stated that they either had no data, or no data for the whole time of existence of the student ticket at the university, or were unsure whether the data was correct for earlier years. In several other cases, the data is not sufficiently comparable over time.

\section{B Proof of Proposition 1}

Firstly, in $t=1$, (21) is always fulfilled because nobody expected a student ticket and all students live at the same distance. Thus, a student ticket exists with certainty in $t=1$.

In later periods, a student ticket must exist if (21) is fulfilled as a strict inequality, given that the middle-cohort students live between the other two cohorts. If a student from another cohort lives at the median distance, we must generalize (22), so that the condition becomes:

$$
\begin{array}{rlrl}
\hat{P}_{t}>\check{P}_{t} \Leftrightarrow c>\frac{2}{3}\left(\frac{D_{t}^{n}+D_{t}^{o}}{2}-D_{t}^{m}\right) k_{a} & \text { if } D_{t}^{n} \geq D_{t}^{m} \geq D_{t}^{o} \\
\hat{P}_{t}>\check{P}_{t} \Leftrightarrow c>\frac{2}{3}\left(\frac{D_{t}^{n}+D_{t}^{m}}{2}-D_{t}^{o}\right) k_{a} & \text { or } D_{t}^{n} \leq D_{t}^{m} \leq D_{t}^{o}, \\
\hat{P}_{t}>\check{P}_{t} \Leftrightarrow c>\frac{2}{3}\left(\frac{D_{t}^{m}+D_{t}^{o}}{2}-D_{t}^{n}\right) k_{a} & & \text { or } D_{t}^{n} \leq D_{t}^{o} \leq D_{t}^{m} & \leq D_{t}^{m}, \\
& & \text { if } D_{t}^{m} \geq D_{t}^{n} \geq D_{t}^{o} \\
& & \text { or } D_{t}^{m} \leq D_{t}^{n} \leq D_{t}^{o} .
\end{array}
$$

The inequalities are hardest to fulfill if the bracketed term becomes as large as possible without invalidating the inequality ordering.

Consider (B.1a). For a given $D_{t}^{m}$, the inequality is hardest to fulfill if the new cohort expects the student ticket with certainty for all the next three periods, $D_{t}^{n}=D^{*}(0)$. At the same time, the maximum value of $D_{t}^{o}$ that keeps the inequality ordering valid is $D_{t}^{o}=D_{t}^{m}$. The condition thus becomes $\hat{P}_{t}>\check{P}_{t} \Leftrightarrow c>\frac{1}{3}\left(D^{*}(0)-D_{t}^{m}\right) k_{a}$. For this, the right-hand side is largest if 
$\left(D_{t}^{o}=\right) D_{t}^{m}=D^{*}\left(k_{a}\right)$, which holds in $t=2$. Thus, if $c>\frac{1}{3}\left(D^{*}(0)-D^{*}\left(k_{a}\right)\right) k_{a}$, there will be definitely be a student ticket in $t=2$; this is the condition given in Proposition 1 .

In $t=3$, the new students from $t=2$ have become the new middle cohort, $D_{3}^{m}=D_{2}^{n}=$ $D^{*}(0)$, and the middle-cohort students from $t=2$ have become the old students in $t=3$, $D_{3}^{o}=D_{2}^{m}=D^{*}\left(k_{a}\right)$. The new ones can only live somewhere inbetween, so (B.1e) becomes the relevant condition and reads $c>\frac{2}{3}\left(\frac{D^{*}(0)+D^{*}\left(k_{a}\right)}{2}-D_{3}^{n}\right) k_{a}$. The right-hand side would become largest if new students would expect the student ticket not to exist, $D_{3}^{n}=D^{*}\left(k_{a}\right)$. But for the same reason as in $t=2$, the student ticket would then be beneficial. The same logic holds in every future period. Anticipating this, new students will thus choose $D_{3}^{n}=D^{*}(0)$. Because this equals $D_{3}^{m}$, the middle-cohort is again at the median distance. Finally, from $t=4 \mathrm{on}$, for the same reason students anticipate that a student ticket will exist for the same reason and new students always choose $D_{t}^{n}=D^{*}(0)$.

\section{References}

Alonso, William, Location and Land Use, Cambridge, Massachussetts: Harvard University Press, 1964.

AStA Darmstadt, "RMV-AStA-Semesterticket," Website of the AStA of the Technical University of Darmstadt, https://www.asta.tu-darmstadt.de/asta/de/angebote/semesterticket March 2015.

AStA Flensburg, "Infos zum Semesterticket," Website of the AStA of the University and of the AStA of the University of Applied Sciences of Flensburg, http://flensburgstudieren.de/de/uni/asta/semesterticket/info March 2015.

AStA Kassel, "FAQ zum Semesterticket," Website of the AStA of the University of Kassel, http://asta-kassel.de/faq-zum-semesterticket April 2015.

AStA Mainz, "Das AStA-Semesterticket," Website of the AStA of the Johannes Gutenberg University of Mainz, http://asta-jgu.de/semesterticket July 2015.

AStA TU, "Semesterticketbüro," Website of the Semesterticket office of the student committees of the Technical University (TU) of Berlin and the Berlin University of Arts, https://asta.tuberlin.de/semtix March 2015.

Brown, Jeffrey, Daniel B. Hess, and Donald Shoup, "Unlimited Access," Transportation, August 2001, 7 (4), 67-84.

_ , _ , and _ , "Fare-Free Public Transit at Universities - An Evaluation," Journal of Planning Education and Research, September 2003, 23 (1), 69-82.

BVerfG, "Beschluss des Bundesverfassungsgerichts vom 04.08.2000," Bundesverfassungsgericht, 1 BvR 1510/99 August 2000.

BVerwG, "Urteil vom 12.5.1999 - 6 C 14.98 - Beitrags-finanziertes Semesterticket," Die Öffentliche Verwaltung, 2000, 2000 (4), 154-157.

Carbajo, Jose C., "The Economics of Travel Passes: Non-uniform Pricing in Transport," Journal of Transport Economics and Policy, May 1988, 12 (2), 153-173.

destatis, Bildung und Kultur: Studierende an Hochschulen, Wintersemester 2013/2014. Fachserie 11, Reihe 4.1, Wiesbaden: Statistisches Bundesamt, 2014. 
_, genesis online database: https://www-genesis.destatis.de, Statistisches Bundesamt, 2015.

Fearnley, Nils, "Free Fares Policy: Impact on Public Transport Mode Share and Other Transport Policy Goals," International Journal of Transportation, December 2013, 1 (1), 75-90.

FitzRoy, Felix and Ian Smith, "Public Transport Demand in Freiburg: Why did Patronage Double in a Decade?," Transport Policy, June 1998, 5 (3), 163-173.

_ and _, "Season Tickets and the Demand for Public Transport," Kyklos, May 1999, 52 (2), 219-238.

Gagiu, Catalin, "Ticket für Studierende wird neu abgestimmt," taz - die tageszeitung, regional edition Berlin, July 102007.

Hebben, Karolin, "Studenten laufen Sturm gegen höhere Preise für Bus und Bahn," OstseeZeitung, October 182014.

HNA, "NVV: Gilt bis nach Göttingen," Hessische Niedersächsische Allgemeine, May 181995.

_ , "Ein Fahrschein für alle," Hessische Niedersächsische Allgemeine, March 12004.

HVV, "Karten für Auszubildende und Studierende," Website of the Hamburger Verkehrsverbund (HVV, http://www.hvv.de/fahrkarten/wochen-monatskarten/karten-azubis-studenten/), March 2015.

_, "Zusammenstellung der Sonderangebote zum Gemeinschaftstarif des Hamburger Verkehrsverbundes (HVV) für die Verbundverkehrsunternehmen," January 2015.

Ibs, Torben, "Für Studenten fährt der Zug ab," taz - die tageszeitung, regional edition Berlin, November 082004.

Lee, Felix and Richard Rother, "Studis springen auf den teuren Zug auf," taz - die tageszeitung, regional edition Berlin, November 172004.

Levinson, David and Andrew Odlyzko, "Too Expensive to Meter: The Influence of Transaction Costs in Transportation and Communication," Philosophical Transactions of the Royal Society A, April 2008, 366 (1872), 2033-2046.

NOZ, "Semesterticket für Uni-Studenten wird teurer," Neue Osnabrücker Zeitung, February 16 2010.

OZ, "Studenten akzeptieren Preis fürs Ticket," Ostsee-Zeitung, December 192014.

Pohl, Joachim, "Semesterticket: Eine Monatskarte für sechs Euro," Flensburger Tageblatt, April 112013.

Pucher, John R. and Steffen Clorer, "Taming the Automobile in Germany," Transportation Quarterly, 1992, 46 (3), 383-395.

RefRat HU, "Semesterticketvertrag und Preise," Website of the Semesterticket office of the student committees of the Humboldt University (HU) of Berlin (ReferentInnenrat) and the Weißensee Kunsthochschule (AStA), http://www.semtix.de/ March 2015.

Schmale, Hendrik, Thomas Ehrmann, and Alexander Dilger, "Buying without Using - Biases of German BahnCard Buyers," Applied Economics, 2013, 45 (7), 933-941. 
Senate of Berlin, "Vertrag zum Semesterticket der TU Berlin wird unterzeichnet," Senate of Berlin, press release, December 062001.

Stadtwerke Mainz, "Studi-Ticket in Mainz wird langfristig fortgeführt," press release, December 102004.

_ , "Studierende und MVG stellen die Weichen für die Zukunft," press release, January 242011.

Stähler, Frank, "Zur Ökonomie des Semestertickets," Jahrbuch für Wirtschaftswissenschaften / Review of Economics, 2000, 51 (1), 92-103.

Storchmann, Karl, "Externalities by Automobiles and Fare-Free Transit in Germany - A Paradigm Shift?," Journal of Public Transportation, 2003, 6 (4), 89-105.

Stricker, Sebastian, "Buslinie 22 verbindet City und Campus Osnabrück," Neue Osnabrücker Zeitung, October 182014.

Tagesspiegel, "Semesterticket - Potsdam macht es vor," July 062004.

University of Osnabrück, "Erweitertes Angebot sinnvoll," Universitätszeitung 99/5, December 151999.

Vance, Colin and Matthias Peistrup, "She's Got a Ticket to Ride: Gender and Public Transit Passes," Transportation, 2012, 39 (6), 1105-1119.

Weichbrodt, Alexander, Das Semesterticket: Illegale Zwangsfahrkarte oder rechtmäßiger Sondertarif für Studierende?, Münster: LIT Verlag, 2001. 